\title{
The injury progression of T lymphocytes in a mouse model with subcutaneous injection of a high dose of sulfur mustard
}

\author{
Yi-Zhou Mei ${ }^{\dagger}$, Xiao-Rui Zhang ${ }^{\dagger}$, Ning Jiang ${ }^{\dagger}$, Jun-Ping Cheng, Feng Liu, Pan Zheng, Wen-Xia Zhou* \\ and Yong-Xiang Zhang*
}

\begin{abstract}
Background: In clinical studies, the findings on sulfur mustard (SM) toxicity for $\mathrm{CD}^{+} \mathrm{CD}^{+}$and $\mathrm{CD}^{+} \mathrm{CD}^{+} \mathrm{T}$ lymphocyte subsets are contradictory. In animal experiments, the effect of SM on the T cell number and proliferation is incompatible and is even the opposite of the results in human studies. In this study, we observed the dynamic changes of T lymphocytes in the first week in a high-dose SM-induced model.

Methods: Mice were exposed to SM by subcutaneous injection (20 mg/kg) and were sacrificed $4 \mathrm{~h}, 24 \mathrm{~h}, 72 \mathrm{~h}$ and $168 \mathrm{~h}$ later. Spleen T lymphocyte proliferation was evaluated by ${ }^{3} \mathrm{H}-\mathrm{TdR}$. Flow cytometric analysis was used to observe the percentage of $\mathrm{CD}^{+}{ }^{+} \mathrm{CD}^{+}$and $\mathrm{CD}^{+}{ }^{+} \mathrm{CD}^{+} \mathrm{T}$ lymphocyte subsets. The IL-1 $\beta, \mathrm{IL}-6, \mathrm{IL}-10$ and TNF- $\mathrm{a}$ levels in plasma were assayed using the Luminex method. DNA damage in bone marrow cells was observed with the single cell gel electrophoresis technique (SCGE).

Results: SM continuously inhibited the proliferation of lymphocytes for 7 days, and there was a significant rebound of Con A-induced T lymphocyte proliferation only at $24 \mathrm{~h}$. The percentage of $\mathrm{CD} 3^{+} \mathrm{CD} 4^{+}$and $\mathrm{CD} 3^{+} \mathrm{CD} 8^{+}$ lymphocytes was upregulated, which was accompanied by increased IL-1 $\beta$ and TNF-a and decreased IL-10. The IL-6 level was gradually decreased in the PG group at $4 \mathrm{~h}$. The peak of lymphocytic apoptosis and DNA damage occurred at $24 \mathrm{~h}$ and $72 \mathrm{~h}$, respectively.

Conclusion: Our results show that SM significantly inhibited T lymphocyte proliferation as well as induced $\mathrm{CD} 3^{+} \mathrm{CD} 4^{+}$ and $\mathrm{CD}^{+} \mathrm{CD}^{+}$upregulation. SM intoxication also significantly increased the levels of pro-inflammatory cytokines (IL-1 $\beta, I L-6$ and TNF-a) and inhibited the level of anti-inflammatory cytokine IL-10. Our results may partly be due to the significant SM induced significant apoptosis and necrosis of lymphocytes as well as DNA damage of bone marrow cells. The results provided a favorable evaluation of SM immune toxicity in an animal model.
\end{abstract}

Keywords: Sulfur mustard, T lymphocyte, Apoptosis, Cytokine, DNA damage

\section{Background}

Sulfur mustard (bis(2-chloroethyl) sulfide, sulfur mustard; $\mathrm{SM}$ ), a highly reactive alkylating agent, was used as a chemical warfare agent in World War I/II and the Iraq/Iran conflict. SM can inflict damage in multiple organs, especially the skin and eyes, as well as the respiratory tract, via complex mechanisms [1-8]. SM can be absorbed into the bloodstream through the skin or digestive tract, thus leading

\footnotetext{
*Correspondence: zhouwx@bmi.ac.cn; zhangyx@bmi.ac.cn

${ }^{\dagger}$ Equal contributors

State Key Laboratory of Toxicology and Medical Countermeasures, Beijing Institute of Pharmacology and Toxicology, Beijing 100850, China
}

to the damage of multiple systems, such as the immune system, and causing subsequent complex changes $[9,10]$. A detailed immunological consequence of SM exposure of Iran victims in the Iraq-Iran war has been reported [11]. The $\mathrm{T}$ cell and monocyte counts in patients exposed to SM reduced to less than $54 \%$ and $65 \%$ of normal within one week after exposure, respectively. However, some studies found that $\mathrm{T}$ lymphocytes were relatively unaffected compared with B lymphocytes after SM exposure in an animal model, which was not consistent with human studies [12]. The proliferation of the remaining $\mathrm{T}$ cells in the presence of Concanavalin $\mathrm{A}$ or to an anti-CD3 
antibody was not significantly affected [12]. Due to the importance of T lymphocytes in SM-induced injury and the contradictory results regarding $\mathrm{T}$ lymphocytes, further investigation was required.

Research in humans showed that, 20 years after the SM exposure, the severely affected victims of the Iran-Iraq war had a lower $\mathrm{CD}^{+} \mathrm{CD}^{+}$level and higher $\mathrm{CD} 3^{+} \mathrm{CD} 8^{+}$level in plasma compared to normal controls [13]. Another study in humans, found that 15 years after sulfur mustard gas exposure, participants had Sezary syndrome and increased $\mathrm{CD}^{+}{ }^{+} \mathrm{CD} 4^{+} / \mathrm{CD}^{+}{ }^{+} \mathrm{CD}^{+}$cells in flow cytometry [14]. Other studies observed increased percentages of $\mathrm{CD}^{+}{ }^{+} \mathrm{CD} 4^{+}$and $\mathrm{CD}^{+}{ }^{+} \mathrm{CD}^{+}{ }^{+} \mathrm{T}$ cells in tissues and body fluids in hairless guinea pigs [15]. The contradictions between human and animal models may be due to the different degrees of injury. The patients in human studies had severe SM exposure, while the animals were exposed to a low dose of SM. In animal experiments, different types of animals, SM doses, exposure routes, and observation times were used. These differences would cause inconsistent conclusions about the effect of $\mathrm{SM}$ on $\mathrm{T}$ lymphocyte proliferation and $\mathrm{CD} 3^{+} \mathrm{CD} 4^{+}$ and $\mathrm{CD}^{+} \mathrm{CD}^{+}{ }^{+} \mathrm{T}$ subsets. Because of the rapid recovery ability of the immune system in mice, we supposed that a higher SM dose is more suitable for developing a mouse model that imitates the toxic process in humans. Therefore, we constructed a high dose SM $(20 \mathrm{mg} / \mathrm{kg})$ exposure mouse model and observed the dynamic state of $\mathrm{T}$ lymphocyte function in this research. Additionally, the homeostasis of proinflammatory and anti-inflammatory cytokines in lymphocytes, apoptosis, necrosis, and DNA damage of bone marrow cells were studied, which would help elucidate the process of SM-induced immune system damage [16-18].

In this research, we developed an SM-induced mouse model by subcutaneous injection of a high dose of SM $(20 \mathrm{mg} / \mathrm{kg}$ ). The dynamic changes of the T lymphocytes in the model were observed at $4 \mathrm{~h}, 24 \mathrm{~h}, 72 \mathrm{~h}$ and $7 \mathrm{~d}$ after SM exposure. This study provides valuable information that could enhance our understanding of the progression of SM toxicity on immune function.

\section{Methods}

\section{Materials}

SM was synthesized by Beijing Institute of Pharmacology and Toxicology and formulated into the desired concentration with 1,2-propanediol solution (Sigma, St. Louis, MO, USA) before use. ${ }^{3} \mathrm{H}-\mathrm{TdR}$ was obtained from the China Institute of Atomic Energy (Beijing, China). RPMI 1640 and calf serum were from Gibco (Carlsbad, CA, USA). APC-anti-CD3, PE-anti-CD4, and FITC-anti-CD8 were from BioLegend (San Diego CA, USA). The Luminex mouse cytokine kit was from Millipore (San Diego, CA, USA). The Annexin V-FITC apoptosis kit was from
Becton, Dickinson and Company (Franklin Lakes, NJ, USA). All other chemicals were obtained from Sigma (St. Louis, MO, USA) unless otherwise indicated.

\section{Animals}

Kunming mice of clean grade, male, weighing 18-22 g, were purchased from the Experimental Animal Center of Beijing Institute of Pharmacology and Toxicology. The animals were acclimatized for 3 days before their use in our experimental work, which was performed according to a specified protocol approved by the Institutional Animal Care and Use Committee (IACUC) of Beijing Institute of Pharmacology and Toxicology. All mice were housed at room temperature $\left(22 \pm 2^{\circ} \mathrm{C}\right), 45 \%-55 \%$ relative humidity, and a 12/12 h light-dark cycle with free access to standard rodent chow and water.

\section{Mouse model induced by subcutaneous injection of SM}

One hundred and sixty Kunming mice were randomly divided into the following three groups: control group, propylene glycol (PG) group and SM exposure group. Animals in the control group, PG group, and SM group received a subcutaneous injection of saline, PG solution, and SM $(20 \mathrm{mg} / \mathrm{kg})$, respectively. The subcutaneous injection volume was $0.1 \mathrm{ml} / 20 \mathrm{~g}$ in all animals, which was continuously observed for 7 days $(168 \mathrm{~h})$. Twelve animals in each group were sacrificed $4 \mathrm{~h}, 24 \mathrm{~h}, 72 \mathrm{~h}$ and $168 \mathrm{~h}$ after exposure.

\section{Lymphocyte proliferation assay}

Mouse lymphocyte proliferation was observed with the ${ }^{3} \mathrm{H}$-thymidine incorporation method [19]. Six Kunming mice per group were sacrificed. Their spleens were aseptically removed and minced through a $40-\mu$ m nylon cell strainer to achieve a single-cell suspension. The red blood cells were depleted with Tris- $\mathrm{NH}_{4} \mathrm{Cl}$ lysis buffer $\left(0.144 \mathrm{~mol} / \mathrm{L} \mathrm{NH}_{4} \mathrm{Cl}, 0.017 \mathrm{~mol} / \mathrm{L}\right.$ Tris$\left.-\mathrm{HCl}\right)$. A total of $5 \times 10^{5}$ spleen cells was stimulated with Con A $(0.5 \mu \mathrm{g} / \mathrm{ml})$. The spleen cells were cultured in RPMI 1640 medium supplemented with $10 \% \mathrm{FBS}$, penicillin $(100 \mathrm{U} / \mathrm{ml})$, and streptomycin $(100 \mu \mathrm{g} / \mathrm{ml})$ at $37^{\circ} \mathrm{C}$ in a $5 \% \mathrm{CO}_{2}$ humidified incubator for $72 \mathrm{~h}$, and they were pulsed with ${ }^{3} \mathrm{H}$-thymidine $(1 \mu \mathrm{Ci} /$ well $)$ during the last $18 \mathrm{~h}$ of incubation. The cells were harvested on glass fiber filters using a Filtermate cell harvester (Packard). The level of ${ }^{3} \mathrm{H}$-thymidine incorporated into the cells was measured with a $\beta$-scintillation counter (Beckman LS6500). The results were expressed as cpm (counters per minute) of the stimulated cells and cpm of the unstimulated cells.

\section{Flow cytometric analysis of $\mathrm{CD}^{+} \mathrm{CD}^{+}$and $\mathrm{CD}^{+} \mathrm{CD}^{+} \mathrm{T}$ lymphocytes}

The lymphocytes were washed with cold PBS containing $0.1 \% \mathrm{NaN}_{3}$ and $1 \% \mathrm{FBS}$. A total of $10^{6}$ cells were incubated 
with APC-conjugated anti-mouse CD3, PE-conjugated anti-mouse CD4 and FITC-conjugated anti-mouse CD8 (BD Biosciences) for $20 \mathrm{~min}$ at room temperature. The cells were washed in PBS containing $0.1 \%$ FBS and analyzed by flow cytometry (BD Calibur $\left.{ }^{\mathrm{Tm}}\right)$.

\section{Plasma cytokine assay by Luminex ${ }^{\mathrm{m}} 200$}

Blood samples from 6 animals in each group were centrifuged $\left(4^{\circ} \mathrm{C}, 3,000 \mathrm{~g} \times 10 \mathrm{~min}\right)$ and then stored at $-70^{\circ} \mathrm{C}$. The levels of IL-1 $\beta$, IL- 6 , IL-10 and TNF- $\alpha$ were analyzed with a cytokine/chemokine kit (MPXMCYTO-70 K-09, Millipore Corporation).

\section{Flow cytometric analysis of apoptosis and necrosis}

To detect phosphatidylserine, annexin V-FITC was used in a combination with propidium iodide (PI) and an ApopNexin FITC Apoptosis Detection Kit (Franklin Lakes, NJ, USA). Every flow tube contained a $0.1 \mathrm{ml}$ cell suspension, and the cells were washed twice with $0.5 \mathrm{ml}$ PBS solution $(1,000 \mathrm{r} / \mathrm{min} \times 5 \mathrm{~min})$. The supernatant was discarded, and then $0.4 \mathrm{ml}$ of binding buffer cell suspension and $5 \mathrm{ml}$ of Annexin- $\mathrm{V}$ were added. After vortex mixing, the tubes were incubated for $15 \mathrm{~min}$ at $4^{\circ} \mathrm{C}$ in the dark. The FITCAnnexin V fluorescence was read with the FL1 photomultiplier tube, and the PI fluorescence was detected using the FL3 channel.

\section{Single cell gel electrophoresis technique (SCGE)}

The DNA damage of bone marrow cells was evaluated by SCGE according to a previous report [20,21]. Briefly, the cells were embedded in agarose and layered on a microscope slide; they were then immersed for $1 \mathrm{~h}$ at $4^{\circ} \mathrm{C}$ in a freshly prepared lysing solution $(2.5 \mathrm{~mol} / \mathrm{L} \mathrm{NaCl}$, $100 \mathrm{mmol} / \mathrm{L} \mathrm{Na}_{2}$-EDTA, and $10 \mathrm{mmol} / \mathrm{L} \mathrm{Tris,} \mathrm{pH} 10$ ) and supplemented immediately prior to use with $1 \%$ N-lauroylsarcosine, 10\% DMSO and 1\% Triton X-100. Following the steps of alkaline unwinding $(\mathrm{pH}>13)$ for $40 \mathrm{~min}$, electrophoresis and neutralization were performed as a standard protocol. All steps were conducted under a dimmed light to prevent additional DNA damage. Following the electrophoresis run, the slides were neutralized and dipped into cold $100 \%$ ethanol. Then, the slides were dried at room temperature before analysis. Fifty cells from each of the duplicate slides were randomly examined under a fluorescence microscope, and the extent of DNA damage was measured using Image-Pro Plus 6.0 (IPP6.0), which performed a software-based analysis of electronic images. DNA damage was quantified as the percentage of comets and the average tail length (TL). The median of each parameter was used as a representative value for each subject, and the mean of the medians was used for statistical analysis.
The formula is: $\mathrm{TL}=(\Sigma$ each cell diameter/total cells $)$

$$
\pm \mathrm{SD}
$$

Percentage of comets $=($ comet cells $/$ measurement cell

$$
\text { number) } \times 100 \%
$$

\section{Statistical analysis}

The data were analyzed by GraphPad Prism Software 5.01 and SPSS Software 13.0 using Student's $t$-test. Data were expressed as the mean $\pm \mathrm{SD}$ and analyzed using one-way ANOVA, which was followed by the Bonferroni $t$-test for multiple comparisons. $P<0.05$ was considered statistically significant.

\section{Results}

\section{Spleen weight and coefficient}

To study the toxicity of SM on immune organs, the spleen weight and coefficient were observed. After subcutaneous injection with SM-PG solution $(20 \mathrm{mg} / \mathrm{kg})$, 6 animals were sacrificed at $4 \mathrm{~h}, 24 \mathrm{~h}, 72 \mathrm{~h}$, and $168 \mathrm{~h}$ after SM exposure. There was no significant difference in the spleen weight or coefficient between the SM group and solvent treatment group (PG group) at $4 \mathrm{~h}$. Significant decreases in the spleen weight and coefficient were observed in the SM group at $24 \mathrm{~h}$ and $72 \mathrm{~h}$ after SM exposure $(P<0.01)$. The results of the weight and coefficient of the spleen are shown in Figure 1A and B. At $168 \mathrm{~h}$, the weight and coefficient of the spleen in the SM group were restored to the normal level.

\section{Spleen lymphocyte proliferation}

The proliferation of peripheral immune cells is directly related to the state of immune function. Previous reports have shown that $\mathrm{SM}$ has no effect on $\mathrm{CD}^{+}{ }^{+} \mathrm{T}$ cell proliferation in a murine model [12]. In this study, we observed spleen lymphocyte proliferation by ${ }^{3} \mathrm{H}-\mathrm{TdR}$ incorporation at $4 \mathrm{~h}, 24 \mathrm{~h}, 72 \mathrm{~h}$ and $168 \mathrm{~h}$ after SM exposure. Con A was used to induce $\mathrm{T}$ lymphocyte proliferation. As shown in Figure (Figure 2A), 4 h, 24 h, 72 h and $168 \mathrm{~h}$ after exposure, lymphocyte proliferation in the SM exposure group was significantly lower than the control group. While Con A-induced T cell proliferation of the SM-exposed group was significantly increased at $72 \mathrm{~h}$ and the T cell proliferation levels of the SMexposed group at $4 \mathrm{~h}, 24 \mathrm{~h}$, and $168 \mathrm{~h}$ were all lower than the PG group (Figure 2B).

\section{Percentage of $\mathrm{CD}^{+} \mathrm{CD}^{+}$and $\mathrm{CD} 3^{+} \mathrm{CD} 8^{+} \mathrm{T}$ lymphocytes}

Previous reports showed that the percentages of $\mathrm{CD}^{+} \mathrm{CD}^{+}$and $\mathrm{CD}^{+}{ }^{+} \mathrm{CD} 8^{+} \mathrm{T}$ lymphocytes were increased in hairless guinea pigs [15], but the changes in the percentages for mice were still unknown. We found that the $\mathrm{CD}^{+} \mathrm{T}$ cells in the spleen were increased gradually after 

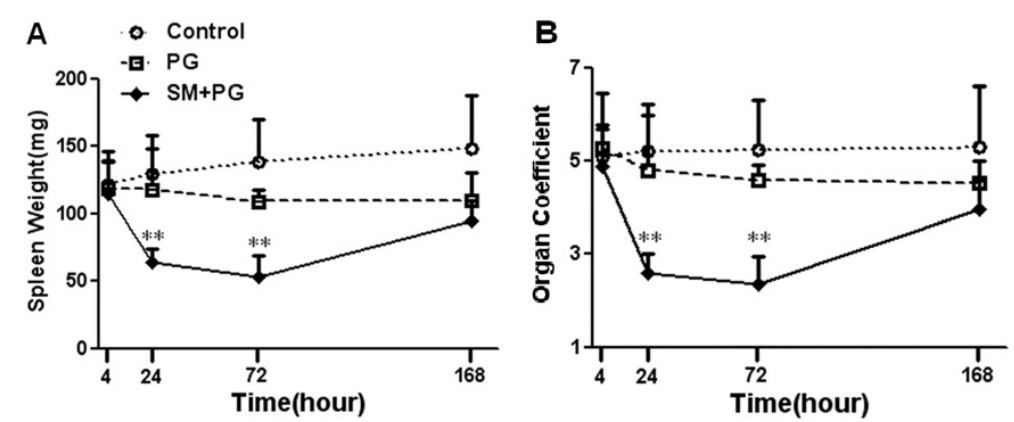

Figure 1 Dynamic decrease in the spleen weight and organ coefficient of the spleen in mice exposed to sulfur mustard (SM). Male KM mice were exposed to saline, propylene glycol (PG) and $20 \mathrm{mg} / \mathrm{kg}$ SM by subcutaneous injection. Six animals from each group were sacrificed after SM exposure at 4 h, 24 h, $72 \mathrm{~h}$ and $168 \mathrm{~h}$, and the spleens were quickly weighed. The spleen weight (A) and organ coefficient of the spleen (B) of every animal were observed to assess SM-induced immune organ injury. Data were presented as the mean \pm SD, $n=6$ in each group (A-B). *Significant difference between the PG treatment and SM exposure groups $\left({ }^{*} P<0.05,{ }^{* *} P<0.01,{ }^{* * *} P<0.001\right)$.

$24 \mathrm{~h}, 72 \mathrm{~h}$, and $168 \mathrm{~h}$ of SM exposure in the SM group (Figure 3A). The percentages of $\mathrm{CD}^{+} \mathrm{CD} 4^{+} \mathrm{T}$ cells were significantly higher than the PG group $24 \mathrm{~h}, 72 \mathrm{~h}$ and $168 \mathrm{~h}$ after exposure $(P<0.01$ or 0.001$)$, shown in Figure 3B. The percentage of $\mathrm{CD}^{+} \mathrm{CD}^{+} \mathrm{T}$ cells was increased at $4 \mathrm{~h}$ after $\mathrm{SM}$ exposure, and it peaked at $72 \mathrm{~h}$ following SM exposure $(P<0.001)$ and then returned to the normal level at $168 \mathrm{~h}$, as shown in Figure 3C.

\section{Changes in the proinflammatory and anti-inflammatory cytokines}

To observe the effects of SM on the balance of proinflammatory and anti-inflammatory cytokines, the levels of proinflammatory cytokines, IL- $1 \beta$, IL- 6 , and TNF- $\alpha$, and the anti-inflammatory cytokine, IL-10, were observed in this study. In the SM group, the IL-1 $\beta$ levels in the plasma at $24 \mathrm{~h}$ and $72 \mathrm{~h}$ were significantly higher than the
PG group $(P<0.05)$, as shown in Figure 4A. The IL-6 levels were decreased in a time-dependent manner and were significantly higher than the PG group at $4 \mathrm{~h}, 24 \mathrm{~h}$ and $72 \mathrm{~h}$ after exposure $(P<0.001)$, as shown in Figure 4B. The level of TNF- $\alpha$ was increased in a time-dependent manner and it was higher than the PG group at $72 \mathrm{~h}$ and $168 \mathrm{~h}$ after SM exposure $(P<0.05)$, as shown in Figure $4 \mathrm{C}$. The IL-10 level in the SM group was decreased from $4 \mathrm{~h}$ to $168 \mathrm{~h}$ after SM exposure and lower than the PG group at $24 \mathrm{~h}$ and $72 \mathrm{~h}(P<0.05$, Figure $4 \mathrm{D})$.

\section{Apoptosis and necrosis of lymphocytes}

The spleen lymphocyte apoptosis and necrosis percentages in the SM group were significantly increased. The spleen lymphocyte apoptosis percentage was higher than the PG group at $4 \mathrm{~h}$ and $24 \mathrm{~h}(P<0.05$ and $P<0.001)$, as shown in Figure 5A1 and B1. Compared to the PG
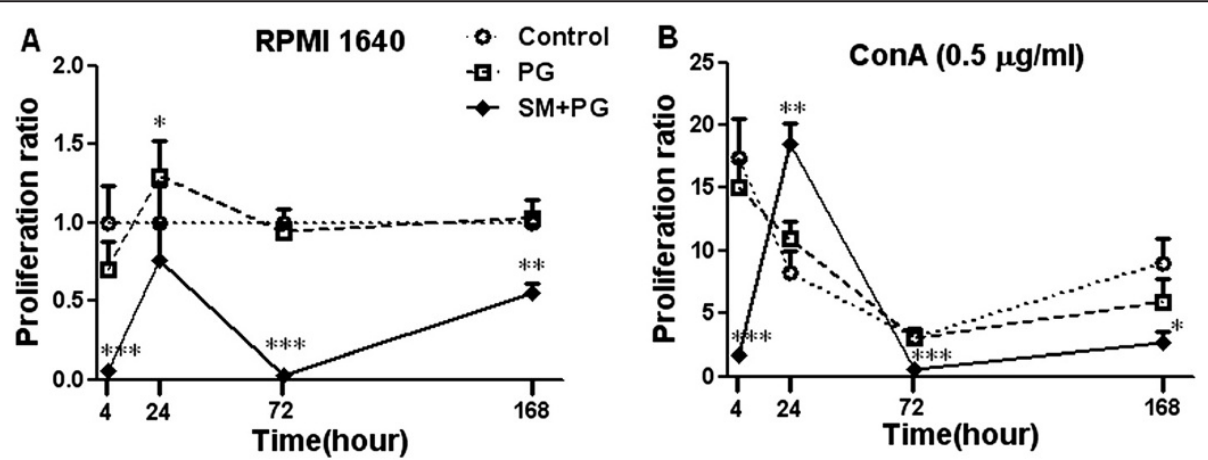

Figure 2 Dynamic changes of the spleen lymphocyte proliferation in mice exposed to sulfur mustard (SM). Male KM mice were exposed to saline, propylene glycol (PG) and $20 \mathrm{mg} / \mathrm{kg}$ SM by subcutaneous injection. Six animals from each group were sacrificed after SM exposure at $4 \mathrm{~h}, 24 \mathrm{~h}, 72 \mathrm{~h}$ and $168 \mathrm{~h}$, and the spleens were prepared in a cell suspension as described in the Materials and Methods, with resulting spleen lymphocytes suspended in RPMl 1640 with 10\% FBS and Concanavalin A (Con A) $(0.5 \mu \mathrm{g} / \mathrm{ml})$. At 56 h after Con A stimulation, $10 \mu \mathrm{l}{ }^{3} \mathrm{H}-\mathrm{TdR}$ was added to each slot. Spleen lymphocyte proliferation was assayed by measuring the ${ }^{3} \mathrm{H}$-TdR of the original proliferation (RPMl 1640) (A) and T lymphocytes (Con A) (B) described in Section 2. The proliferation ratio of the control group was set to 1.0, and data were presented as the fold increases compared with their respective vehicle controls. ${ }^{*}$ Significant difference between the PG treatment and SM exposure group $\left({ }^{*} P<0.05,{ }^{* *} P<0.01,{ }^{* * *} P<0.001\right)$. Data were presented as the mean $\pm S D, n=6$ in each group (A-B). 


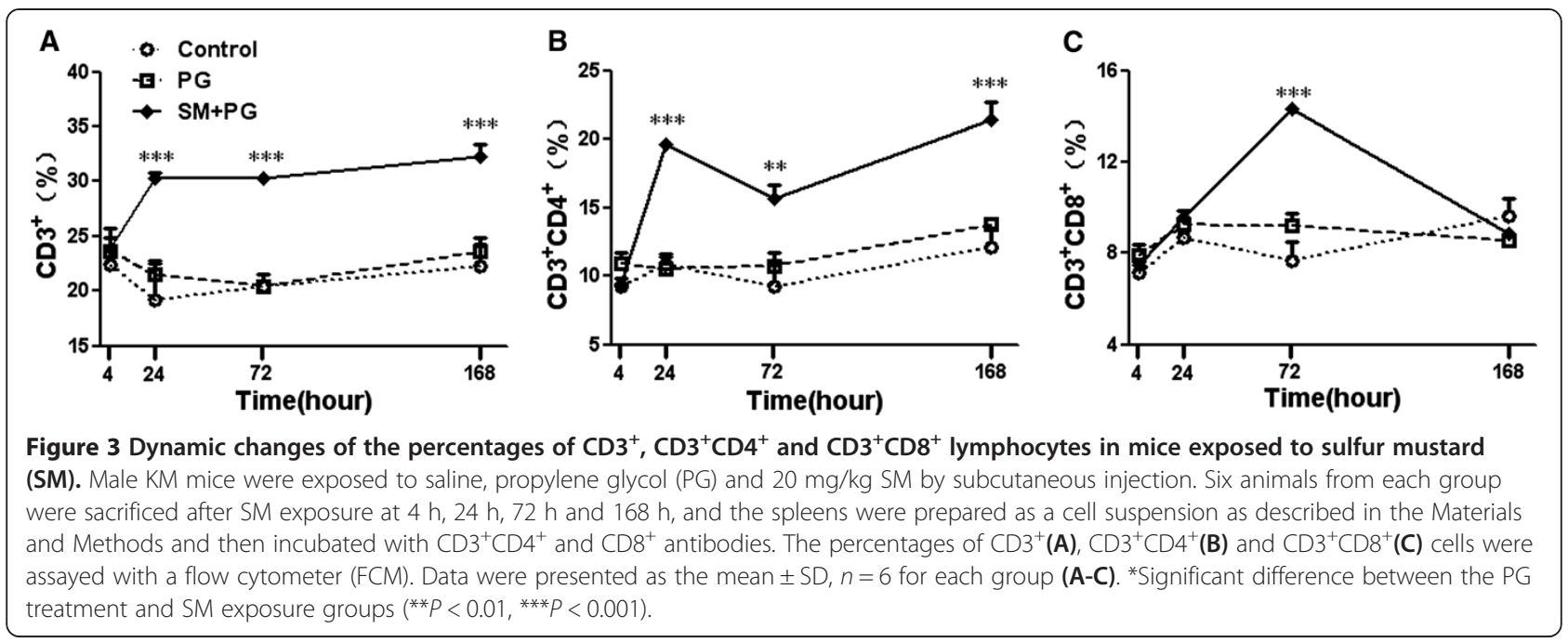

group, the necrosis of the SM group was significantly higher than the PG group at $4 \mathrm{~h}, 24 \mathrm{~h}$ and $72 \mathrm{~h}(P<0.01$ or $P<0.001$ ), as shown in Figure 5A2 and B2.

\section{DNA damage of the bone marrow cells}

As an alkylating agent, SM is particularly toxic to rapidly proliferating cells, such as lymphoid and bone marrow cells. It was reported that bone marrow $\mathrm{T}$ or stem cells have an important immunoregulation function [22,23]. Bone marrow cell proliferation and differentiation were so active that DNA was sensitive to SM alkylation [24,25]. Therefore, we observed DNA damage of the bone marrow nucleated cells after SM exposure by SCGE. The bone marrow cells appear to demonstrate remarkably dynamic

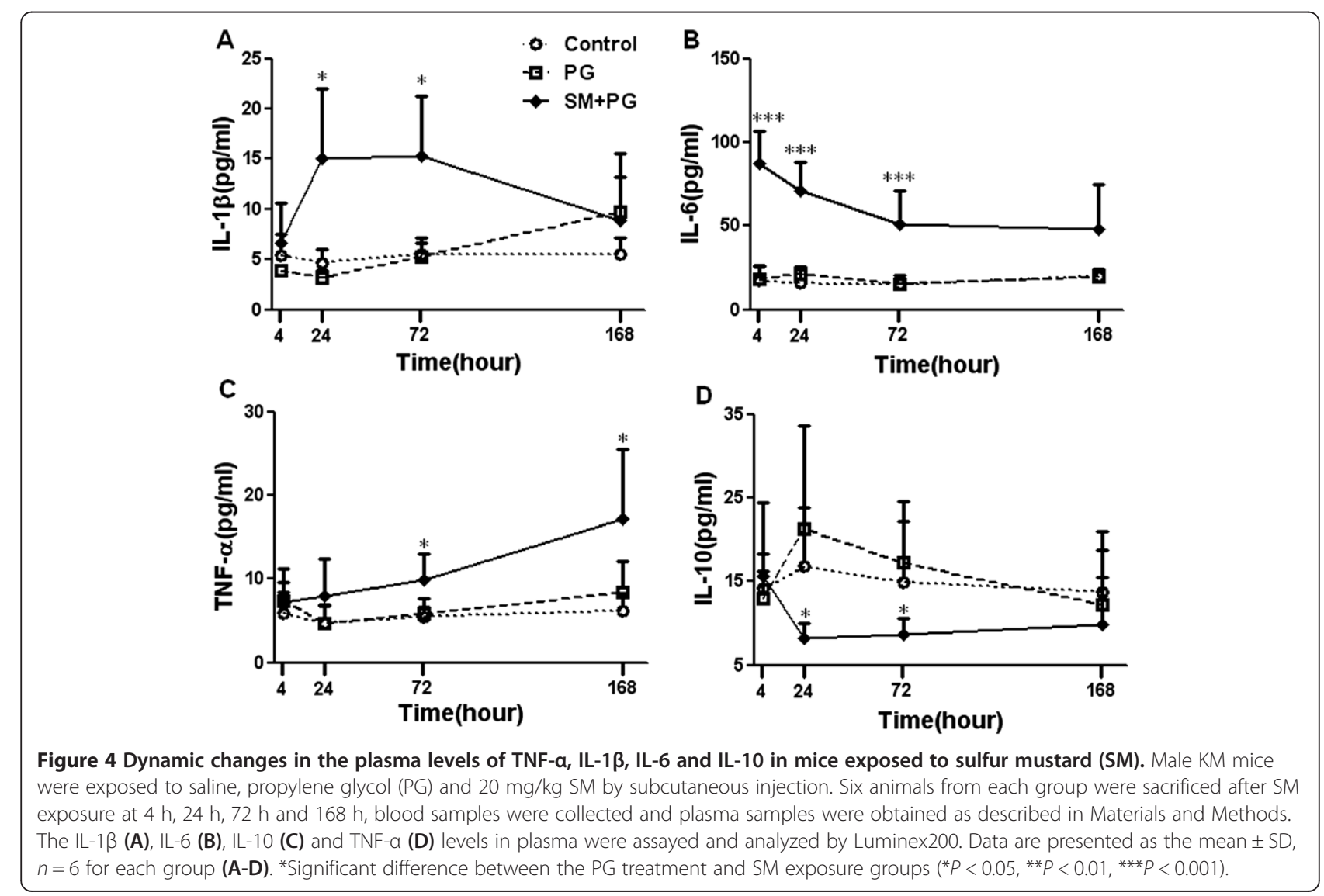



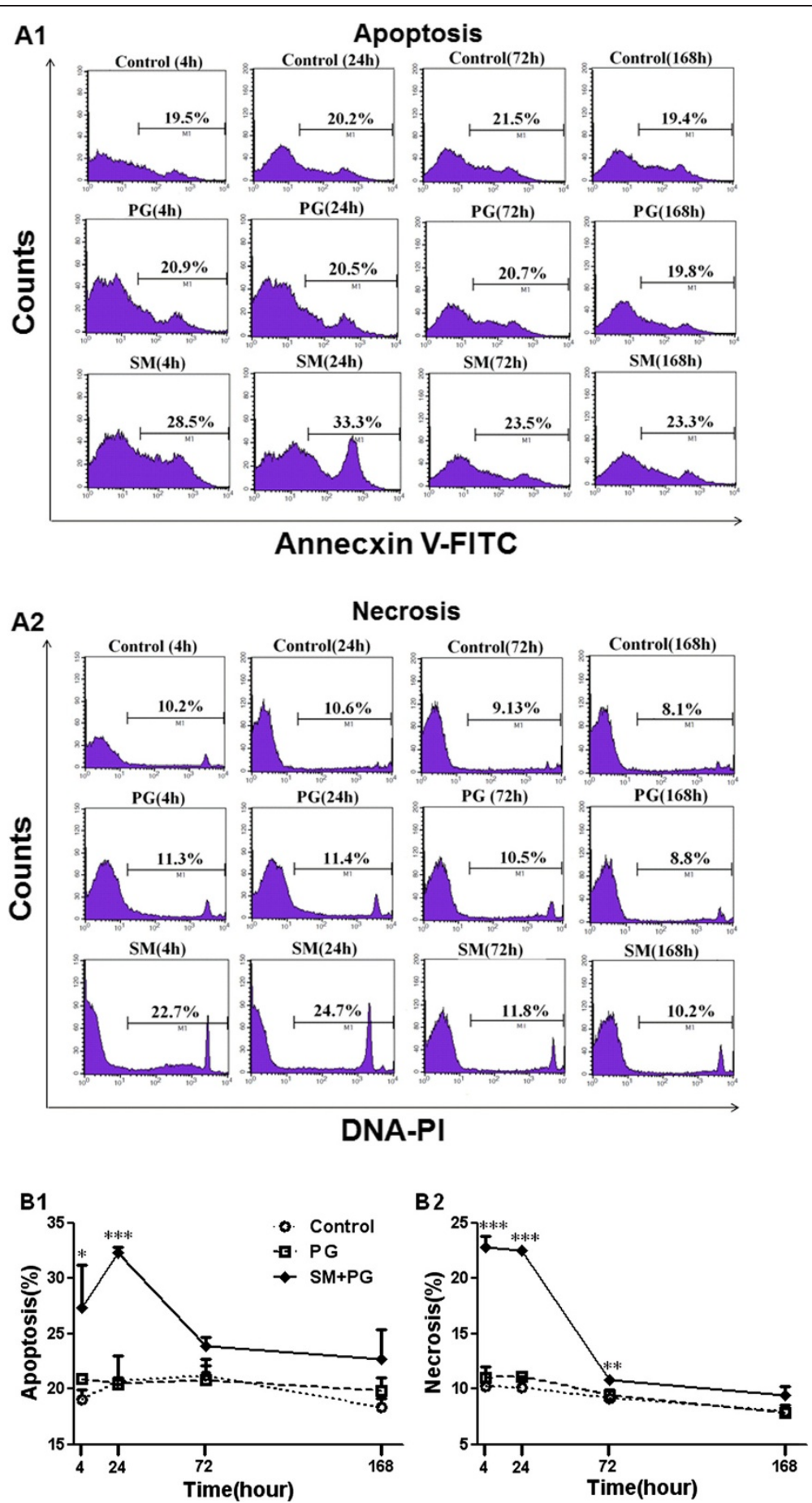

Figure 5 Apoptosis and necrosis of splenic lymphocytes in mice exposed to sulfur mustard (SM). Male KM mice were exposed to saline, propylene glycol (PG) and $20 \mathrm{mg} / \mathrm{kg}$ SM by subcutaneous injection. Six animals from each group were sacrificed after SM exposure at $4 \mathrm{~h}, 24 \mathrm{~h}$, $72 \mathrm{~h}$ and $168 \mathrm{~h}$, and the spleens were quickly collected. The spleens were prepared as cell suspensions as described in the Materials and Methods and then incubated with FITC and PI. Spleen lymphocyte necrosis $\left(\mathrm{PI}^{+}\right)$and apoptosis $\left(\mathrm{FITC} \mathrm{C}^{+} \mathrm{I}^{+}\right)$were assayed with a flow cytometer (FCM) (A1-A2). Data are presented as the mean $\pm S D, n=6$ for each group (B1-B2). ${ }^{*}$ Significant difference between the PG treatment and SM exposure groups (*P $<0.05$, **P $\left.<0.01,{ }^{* * *} P<0.001\right)$. 
DNA damage after SM exposure (Figure 6A). The percentage of commets and the "tail length" (TL) had positive correlation with the degree of DNA damage. At $4 \mathrm{~h}$ after exposure, approximately $12 \%$ of the cells were damaged in the SM group, but the TL was not significantly different from the PG group. At $24 \mathrm{~h}$ after exposure, the percentage of comets reached $30 \%$, and the TL was three times longer than that of the PG group. At $72 \mathrm{~h}$, the percentage of comets reached $85 \%$, and the TL was 10 times that of the control group, and the number of cells was greatly reduced. At $168 \mathrm{~h}$ after exposure, the percentage of comets, $\mathrm{TL}$ and number of bone marrow cells in the SM group were decreased, but their numbers were still significantly different compared to the PG group (Figure 6B).

\section{Discussion}

SM is a powerful chemical warfare agent (CWA) that was extensively used during World War I/II and more recently in the Iran-Iraq war of the 1980s. In addition to its military use, it is a potential weapon of mass destruction against civilians that causes both acute and chronic health effects $[26,27]$. The chemical weapons discarded by invading Japanese troops during the War of Resistance against Japanese Invasion are threatening the safety and homes of Chinese people. Forty-three people were poisoned by abandoned Japanese mustard gas, which left one person dead in August 2003. Several researchers found that peripheral blood $\mathrm{T}$ lymphocytes, monocytes, macrophages, neutrophils, endothelial and epithelial cells in the gut as well as bone marrow cells were sensitive to SM. These cell types were susceptible to apoptosis and necrosis, and the main reason for necrosis may be related to DNA breaks by SM alkylation $[28,29]$. Other important injury factors, such as inflammatory and oxidative stress, may be important cofactors in increasing the toxicity of SM [30].

The effect of SM on human T lymphocyte proliferation has not been previously reported. Some animal studies have reported that SM exposure causes severe lymphocyte function suppression with progressively decreased splenocyte

\section{A}



Control

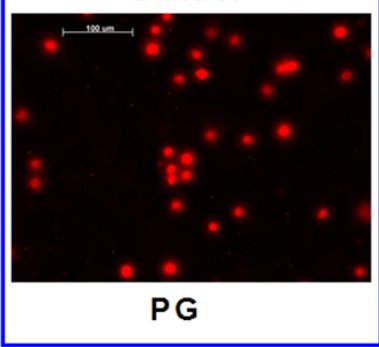

B1

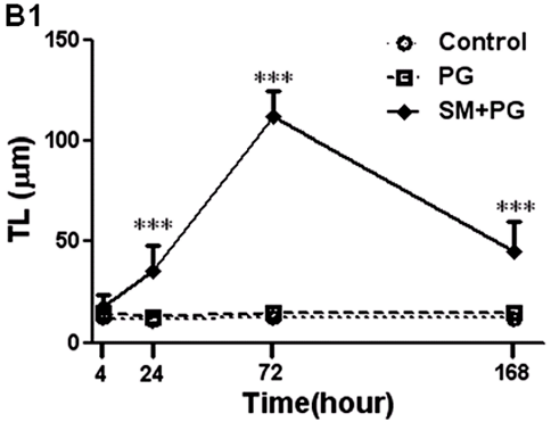

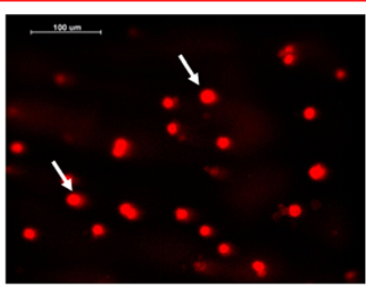

SM 4h

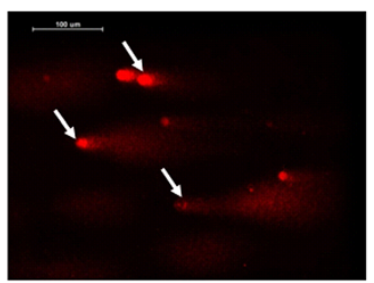

SM $72 h$

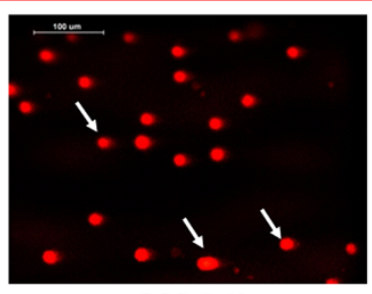

SM 24h

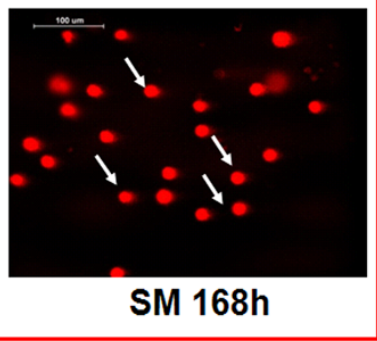

B2

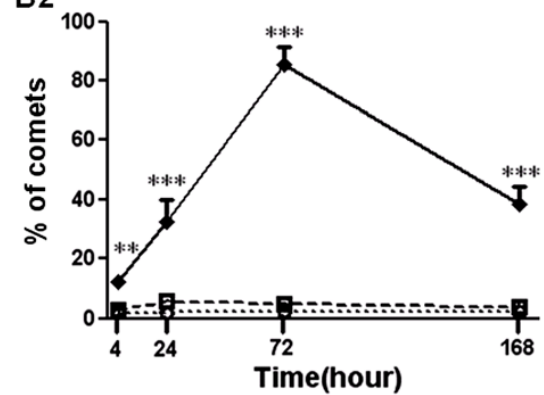

Figure 6 DNA damage of the bone marrow cells in mice exposed to sulfur mustard (SM). Male KM mice were exposed to saline, propylene glycol (PG) and 20 mg/kg SM by subcutaneous injection. Six animals from each group were sacrificed after SM exposure at 4 h, 24 h, 72 h and $168 \mathrm{~h}$, and a bone marrow cell suspension was prepared and assayed by single cell gel electrophoresis technique (SCGE) as described in the Materials and Methods (A). The TL (B1) and the percentage of comets (B2) were evaluated to assess SM-induced DNA damage. Data are presented as the mean $\pm S D, n=6$ for each group (B1-B2). *Significant difference between the PG treatment and SM exposure groups (**P $<0.01$, $\left.{ }^{* * *} P<0.001\right)$. 
proliferation that recovered up to the fifth day after exposure [31]. While others have reported that SM does not depress murine $\mathrm{T}$ lymphocyte proliferation in response to Concanavalin A or to an anti-CD3 antibody, $\mathrm{B}$ cell proliferation in the presence of lipopolysaccharide is not significantly impaired [12]. In this study, we found that, in a mouse model induced by subcutaneous injection, the primary proliferations of splenocytes at 4, 24, 72 and $168 \mathrm{~h}$ were significantly lower than in the PG group, and the Con A-induced $\mathrm{T}$ cell proliferation was significantly lower than in the PG group at $4 \mathrm{~h}, 72 \mathrm{~h}$ and $168 \mathrm{~h}$, while $24 \mathrm{~h}$ was significantly higher. Coutelier et al. [12] found that SM-induced systemic intoxication did not depress $\mathrm{T}$ lymphocyte function as their proliferation in response to concanavalin A or to an anti-CD3 antibody was not affected by the treatment. Another study showed that cyclophosphamide, a commonly used chemotherapy drug and alkylating agent, could adjust immune function by enhancing lymphocyte proliferation in animal models [32]. $\mathrm{SM}$ is an alkylating agent with a similar mechanism of action to that of cyclophosphamide. Therefore, the reason that a dose lower than the LD50 of SM exposure caused $\mathrm{T}$ and $\mathrm{B}$ cell proliferation rebound at an early time of SM intoxication may be similar to the enhancement of cyclophosphamide to immune cell proliferation as a hormesis.

Twenty years after SM exposure, victims of the IranIraq war had a lower $\mathrm{CD}^{+}$level and higher $\mathrm{CD} 8^{+}$level in plasma compared to control subjects, suggesting that the SM caused a long-term suppression of the immune system [13]. Our results in a mouse model found that the spleen weights were significantly decreased at $24 \mathrm{~h}$ and $72 \mathrm{~h}$, and they gradually recovered to a control level at $168 \mathrm{~h}$ after a high-dose $(20 \mathrm{mg} / \mathrm{kg})$ of SM. Spleen lymphocyte apoptosis and necrosis were observed at $4 \mathrm{~h}$ and recovered after $72 \mathrm{~h}$. In T cell subsets, the percentages of $\mathrm{CD} 3^{+} \mathrm{CD} 4^{+}$and $\mathrm{CD} 3^{+} \mathrm{CD} 8^{+} \mathrm{T}$ cells were higher than the PG group. The percentage of $\mathrm{CD}^{+} \mathrm{CD}^{+} \mathrm{T}$ cells was higher than the PG group, which may be due to the decrease in the number of mononuclear macrophages, which was reduced $90 \%$ in human blood [11]. These results are consistent with other studies reporting observations after percutaneous exposure and inhalation of SM in which researchers not only observed an increasing percentage of $\mathrm{CD}^{+}$and $\mathrm{CD}^{+} \mathrm{T}$ cells in tissues and body fluids, which is consistent with our results. These studies also observed an increasing ratio of $\mathrm{CD}^{+} / \mathrm{CD}^{+} \mathrm{T}$ cells and inflammatory injuries at exposure positions, suggesting that SM systemic exposure selectively affects $\mathrm{T}$ cell activity and the percentage of $\mathrm{T}$ cell subsets as well as causes an imbalance of related inflammatory cytokines [15].

Many studies on immunological and inflammatory changes in skin and corneas after acute intoxication as well as long-term chronic immune system diseases caused by SM exposure have been reported [15,33-36]. Many cytokines, such as TNF- $\alpha$, IL- $1 \alpha$, IL-1 $\beta$, IL-4, IL-6, IL-8, IL-10, IL-12, IL-13, IL-15, IL-17, TGF- $\beta$, G-CSF, IGF-1 (insulin-like growth factor-1), EGF (epidermal growth factor), GM-CSF, and IFN- $\gamma$, are closely related to the toxicity of SM [15,37-40]. The levels of these cytokines vary in different SM injuries. For example, IL-17 likely plays an important role in the pathogenesis of SMinduced lung injury [39]. The numbers and proliferation activity of T cells could affect the levels of many cytokine types $[39,41,42]$. A variety of cytokines secreted by $\mathrm{T}$ cells, including IL- $1 \beta$, IL- 6 , IL-10 and TNF- $\alpha$, are reported to be associated with respiratory damage. IL-1 $\beta$, IL- 6 and TNF- $\alpha$ are pro-inflammatory cytokines [43-45], while IL-10 is closely related to the antiinflammatory mechanisms of the body [46]. In this research, we observed dynamic changes in the proinflammatory cytokines (TNF- $\alpha$, IL- $1 \beta$ and IL-6) and anti-inflammatory cytokine (IL-10). We found that the IL-1 $\beta$ levels in plasma were significantly higher than the PG group at $24 \mathrm{~h}$ and $72 \mathrm{~h}$ after SM exposure, but the TNF- $\alpha$ level did not increase significantly until $72 \mathrm{~h}$ after exposure. Some studies demonstrated that the IL- $1 \beta$ and TNF- $\alpha$ levels were significantly increased in $\mathrm{HaCaT}$ cells and respiratory alveolar exudates, which was associated with skin irritation and blistering airway inflammatory exudate 6-48 h after SM exposure [40,47]. The time points of increasing the IL- $1 \beta$ and TNF- $\alpha$ levels were different from our results, which may be related to the various tissue distributions from various exposure models. We found that each of the two inflammatory cytokines induced injury at different time points and led to an inflammatory-sensitive state with an increase in IL- $1 \beta$ at the early phase and in TNF- $\alpha$ at the late phase. As a proinflammatory cytokine [43], the level of IL-6 was increased after SM exposure in our study. Then, when splenocyte apoptosis increased and necrosis reduced, the IL- 6 level gradually decreased from a significantly higher level, but it was still significantly higher than the PG group at all four time points. Interestingly, when the IL-6 level was highest at $4 \mathrm{~h}$, the splenocyte apoptosis percentage of the SM group was not significantly different compared to the PG group; meanwhile, the necrosis percentage was also at the highest level. In vivo studies found that the serum IL-6 was increased in patients with sulfur mustard poisoning and COPD [48]. In vitro, treatment with $100 \mu \mathrm{mol} / \mathrm{L}$ of SM for 24 hours resulted in a significantly increased level of IL-6 secretion by human epidermal keratinocytes (HEKs) and human skin fibroblasts (HSFs) [49]. These results were consistent with our finding that the IL-6 level increased after SM exposure. The main sources of IL- 6 are monocytes, macrophages, $\mathrm{T}$ and $\mathrm{B}$ cells, fibroblasts, 
epithelial cells, and smooth muscle cells [48]. Therefore, we speculated that the gradual decrease in IL-6 was mainly due to the significant necrosis and apoptosis of $\mathrm{T}$ and B lymphocytes in the intoxicated spleen. IL-10 is an anti-inflammatory cytokine $[50,51]$ that is produced by various types of activated immune cells. The IL-10 levels were significantly lower than the PG group at $24 \mathrm{~h}$ and $72 \mathrm{~h}$, while the spleen coefficient, T-lymphocyte proliferation and apoptosis proportion were all at the lowest level. The decrease in IL-10 suggested a low antiinflammatory capacity, which might relate to the general toxic injuries. These results demonstrated that SM exposure could cause an imbalance of the proinflammatory and anti-inflammatory cytokines.

The immune cells (especially $\mathrm{T}$ and $\mathrm{B}$ cells) are originated from bone marrow cells $[22,23,52,53]$, which is one of the most sensitive tissues to SM alkylation due to its hyperactive proliferation and differentiation. DNA damage is reported as a key consequence of SM exposure, occurring either via direct DNA alkylation by SM or via oxidative or nitrosative stress [54,55]. Therefore, we observed dynamic DNA damage of the bone marrow cells in the SM subcutaneous injection mouse model with SCGE. DNA damage in the bone marrow cells was apparent at $4 \mathrm{~h}$ and increased to peak at $72 \mathrm{~h}$; it then decreased at $168 \mathrm{~h}$, but it was still higher than the PG group. The result was similar to the dynamic changes of apoptosis and necrosis in splenocytes, indicating that DNA damage may be the main and direct reason of cell apoptosis and necrosis, and the difference in the time course may be due to the differential tissue distribution of SM [56].

\section{Conclusions}

SM significantly inhibited T lymphocyte proliferation and increased the percentages of $\mathrm{CD}^{+} \mathrm{CD}_{4}^{+}$and $\mathrm{CD}^{+} \mathrm{CD}^{+}$. This may be due to the SM-induced apoptosis and necrosis of $\mathrm{T}$ lymphocytes, the disturbance of proinflammatory and anti-inflammatory cytokines, and DNA damage in bone marrow cells. These results improve our understanding of immune function in an SM toxicity mouse model.

\footnotetext{
Abbreviations

Con A: Concanavalin A; CPM: Counters per minute; CWA: Chemical warfare agent; EGF: Epidermal growth factor; FCM: Flow cytometer; GM-CSF: Granulocyte-macrophage colony stimulating factor; HEKs: Human epidermal keratinocytes; HSFs: Human skin fibroblasts; IACUC: Institutional Animal Care and Use Committee; IGF: Insulin-like growth factor; IL: Interleukin; PG: Propylene glycol; PI: Propidium iodide; SCGE: Single cell gel electrophoresis technique; SM: Sulfur mustard; TL: Tail length; TNF: Tumor necrosis factor.
}

\section{Competing interests}

The authors declare that they have no competing interests.

\section{Authors' contributions}

The authors contributed to this study as follows: YM, XZ, NJ, WZ and YZ designed the study; YM, NJ and XZ wrote the manuscript; YM, JC, FL and PZ performed the experiments; $Y M$ analyzed the data and prepared the figures; and $Y M, N J$ and $X Z$ drafted the manuscript. All authors have read and approved of the final manuscript.

\section{Acknowledgements}

This work was supported by grants from the military medical science foundation projects (08G142), Chinese scientific and technological major special project (2009ZXJ09002-012, 2013ZX09J13103-01B and 2014ZX09J14103-03A), and state key laboratory of toxicology and medical countermeasures.

\section{Conflicts}

This manuscript is our original, unpublished work, and it has not been submitted for publication elsewhere while under consideration at Military Medical Research. All authors confirm that they have read and approved of the paper. It will not be published elsewhere in the same form, in either the same or another language, without the consent of the editors and publisher. The animal experiments were carried out according to a specified protocol approved by the Institutional Animal Care and Use Committee (IACUC) of Beijing Institute of Pharmacology and Toxicology.

Received: 13 June 2014 Accepted: 1 December 2014

Published online: 19 December 2014

\section{References}

1. Bhattacharya R, Rao PV, Pant SC, Kumar P, Tulsawani RK, Pathak U, Kulkarni A, Vijayaraghavan R: Protective effects of amifostine and its analogues on sulfur mustard toxicity in vitro and in vivo. Toxicol Appl Pharmacol 2001, 176:24-33.

2. Vijayaraghavan R, Kulkarni A, Pant SC, Kumar P, Rao PV, Gupta N, Gautam A, Ganesan K: Differential toxicity of sulfur mustard administered through percutaneous, subcutaneous, and oral routes. Toxicol Appl Pharmacol 2005, 202:180-188.

3. Hess JF, FitzGerald PG: Treatment of keratin intermediate filaments with sulfur mustard analogs. Biochem Biophys Res Commun 2007, 359:616-621.

4. Calvet JH, Planus E, Rouet P, Pezet S, Levame M, Lafuma C, Harf A, D'Ortho MP: Matrix metalloproteinase gelatinases in sulfur mustard-induced acute airway injury in guinea pigs. Am J Physio/ 1999, 276:L754-L762.

5. Firooz A, Komeili A, Dowlati Y: Eruptive melanocytic nevi and cherry angiomas secondary to exposure to sulfur mustard gas. J Am Acad Dermatol 1999, 40:646-647.

6. Noort D, Hulst AG, de Jong LP, Benschop HP: Alkylation of human serum albumin by sulfur mustard in vitro and in vivo: mass spectrometric analysis of a cysteine adduct as a sensitive biomarker of exposure. Chem Res Toxicol 1999, 12:715-721.

7. Heston WE: Occurrence of tumors in mice injected subcutaneously with sulfur mustard and nitrogen mustard. J Nat/ Cancer Inst 1953, 14:131-140.

8. Elsayed NM, Omaye ST, Klain GJ, Korte DW Jr: Free radical-mediated lung response to the monofunctional sulfur mustard butyl 2-chloroethyl sulfide after subcutaneous injection. Toxicology 1992, 72:153-165.

9. Cowan FM, Broomfield CA, Smith WJ: Sulfur mustard exposure enhances Fc receptor expression on human epidermal keratinocytes in cell culture: implications for toxicity and medical countermeasures. Cell Biol Toxicol $1998,14: 261-266$.

10. Hamilton MG, Dorandeu FM, McCaffery M, Lundy PM, Sawyer TW: Modification of cytosolic free calcium concentrations in human keratinocytes after sulfur mustard exposure. Toxicol In Vitro 1998, 12:365-372.

11. Hassan ZM, Ebtekar M: Immunological consequence of sulfur mustard exposure. Immunol Lett 2002, 83:151-152.

12. Coutelier JP, Lison D, Simon O, Willems J: Effect of sulfur mustard on murine lymphocytes. Toxicol Lett 1991, 58:143-148.

13. Emad A, Emad Y: Increased in CD8 T lymphocytes in the BAL fluid of patients with sulfur mustard gas-induced pulmonary fibrosis. Respir Med 2007, 101:786-792.

14. Emadi SN, Babamahmoodi F, Poursaleh Z, Sayad-Noori SS, Soroush MR, Maleki AR, Izadi M, Khodaei-Ardakan MR, Emadi SE: Sezary syndrome, Kaposi sarcoma and generalized dermatophytosis 15 years after sulfur mustard gas exposure. J Dermatol Case Rep 2012, 6:86-89.

15. Mishra NC, Rir-sima-ah J, March T, Weber W, Benson J, Jaramillo R, Seagrave JC, Schultz G, Grotendorst G, Sopori M: Sulfur mustard induces immune sensitization in hairless guinea pigs. Int Immunopharmacol 2010, 10:193-199. 
16. Mol MA, de Vries-van de Ruit AM: Concentration- and time-related effects of sulphur mustard on human epidermal keratinocyte function. Toxicol In Vitro 1992, 6:245-251.

17. Lin $P$, Vaughan $F L$, Bernstein IA: Formation of interstrand DNA cross-links by bis-(2-chloroethyl)sulfide (BCES): a possible cytotoxic mechanism in rat keratinocytes. Biochem Biophys Res Commun 1996, 218:556-561.

18. Moser J, Levine CF, Thomas-Dunmeyer DR, Smith WJ: Cross-linking interferes with assessing sulfur mustard-induced DNA damage in human peripheral blood lymphocytes using the comet assay. Toxicol Mech Methods 2004, 14:195-202.

19. Zhang XR, Qi CH, Cheng JP, Liu G, Huang LJ, Wang ZF, Zhou WX, Zhang YX: Lycium barbarum polysaccharide LBPF4-OL may be a new Toll-like receptor 4/MD2-MAPK signaling pathway activator and inducer. Int Immunopharmacol 2014, 19:132-141.

20. Singh NP, McCoy MT, Tice RR, Schneider EL: A simple technique for quantitation of low levels of DNA damage in individual cells. Exp Cell Res 1988, 175:184-191.

21. Fracasso ME, Doria $D$, Franceschetti $P$, Perbellini $L$, Romeo $L$ : DNA damage and repair capacity by comet assay in lymphocytes of white-collar active smokers and passive smokers (non- and ex-smokers) at workplace. Toxicol Lett 2006, 167:131-141.

22. Ribeiro A, Laranjeira P, Mendes S, Velada I, Leite C, Andrade P, Santos F, Henriques A, Grãos M, Cardoso CM, Martinho A, Pais M, da Silva CL, Cabral J, Trindade H, Paiva A: Mesenchymal stem cells from umbilical cord matrix, adipose tissue and bone marrow exhibit different capability to suppress peripheral blood B, natural killer and T cells. Stem Cell Res Ther 2013, 4:125.

23. Domschke C, Ge Y, Bernhardt I, Schott S, Keim S, Juenger S, Bucur M, Mayer L, Blumenstein M, Rom J, Heil J, Sohn C, Scheeweiss A, Beckhove P, Schuetz F: Long-term survival after adoptive bone marrow $T$ cell therapy of advanced metastasized breast cancer: follow-up analysis of a clinical pilot trial. Cancer Immunol Immunother 2013, 62:1053-1060.

24. Balali-Mood M, Hefazi M: The pharmacology, toxicology, and medical treatment of sulphur mustard poisoning. Fundam Clin Pharmacol 2005, 19:297-315.

25. Dacre JC, Goldman M: Toxicology and pharmacology of the chemical warfare agent sulfur mustard. Pharmacol Rev 1996, 48:289-326.

26. Benschop HP, van der Schans GP, Noort D, Fidder A, Mars-Groenendijk RH, de Jong LP: Verification of exposure to sulfur mustard in two casualties of the Iran-Iraq conflict. J Anal Toxicol 1997, 21:249-251.

27. Ghanei M, Poursaleh Z, Harandi AA, Emadi SE, Emadi SN: Acute and chronic effects of sulfur mustard on the skin: a comprehensive review. Cutan Ocul Toxicol 2010, 29:269-277.

28. Black RM, Hambrook JL, Howells DJ, Read RW: Biological fate of sulfur mustard, 1,1'-thiobis(2-chloroethane). Urinary excretion profiles of hydrolysis products and beta-lyase metabolites of sulfur mustard after cutaneous application in rats. J Anal Toxicol 1992, 16:79-84.

29. Maisonneuve A, Callebat I, Debordes L, Coppet L: Biological fate of sulphur mustard in rat: toxicokinetics and disposition. Xenobiotica 1993, 23:771-780.

30. Kehe K, Balszuweit F, Steinritz D, Thiermann H: Molecular toxicology of sulfur mustard-induced cutaneous inflammation and blistering. Toxicology 2009, 263:12-19.

31. Ebtekar M, Hassan ZM: Effect of immunomodulators pyrimethamine and cimetidine on immunosuppression induced by sulfur mustard in mice. Int J Immunopharmacol 1993, 15:533-541.

32. Proietti E, Greco G, Garrone B, Baccarini S, Mauri C, Venditti M, Carlei D, Belardelli F: Importance of cyclophosphamide-induced bystander effect on $T$ cells for a successful tumor eradication in response to adoptive immunotherapy in mice. J Clin Invest 1998, 101:429-441.

33. Millard CB, Bongiovanni R, Broomfield CA: Cutaneous exposure to bis-(2-chloroethyl)sulfide results in neutrophil infiltration and increased solubility of $180,000 \mathrm{mr}$ subepidermal collagens. Biochem Pharmacol 1997, 53:1405-1412.

34. Rowell M, Kehe K, Balszuweit F, Thiermann H: The chronic effects of sulfur mustard exposure. Toxicology 2009, 263:9-11.

35. Ghasemi H, Mostafaie A, Yaraee R, Hassan ZM, Rezaei A, Mahmoudi M, Faghihzadeh S, Soroush MR, Ardestani SK, Babaei M, Jalali-Nadoushan M, Khamesipour A, Ghassemi-Broumand M, Ghazanfari T: Association of serum immunoglobulins levels and eye injuries in sulfur mustard exposed: Sardasht-Iran Cohort Study. Int Immunopharmacol 2013, 17:944-951.

36. Ruff AL, Jarecke AJ, Hilber DJ, Rothwell CC, Beach SL, Dillman JF 3rd: Development of a mouse model for sulfur mustard-induced ocular injury and long-term clinical analysis of injury progression. Cutan Ocul Toxicol 2013, 32:140-149.

37. Ruff AL, Dillman JF 3rd: Sulfur mustard induced cytokine production and cell death: investigating the potential roles of the p38, p53, and NF-kappaB signaling pathways with RNA interference. J Biochem $\mathrm{Mol}$ Toxicol 2010, 24:155-164.

38. Gao X, Ray R, Xiao Y, Barker PE, Ray P: Inhibition of sulfur mustard-induced cytotoxicity and inflammation by the macrolide antibiotic roxithromycin in human respiratory epithelial cells. BMC Cell Biol 2007, 8:17.

39. Mishra NC, Rir-sima-ah J, Grotendorst GR, Langley RJ, Singh SP, Gundavarapu S, Weber WM, Pena-Philippides JC, Duncan MR, Sopori ML: Inhalation of sulfur mustard causes long-term T cell-dependent inflammation: possible role of Th17 cells in chronic lung pathology. Int Immunopharmacol 2012, 13:101-108.

40. Karacsonyi C, Shanmugam N, Kagan E: A clinically relevant in vitro model for evaluating the effects of aerosolized vesicants. Toxicol Lett 2009, 185:38-44.

41. Ekstrand-Hammarstrom B, Wigenstam E, Bucht A: Inhalation of alkylating mustard causes long-term T cell-dependent inflammation in airways and growth of connective tissue. Toxicology 2011, 280:88-97.

42. Zabrodskii PF, Germanchuk VG, Mandych VG: Inhibition of function of T cell subpopulations and decrease in cytokine production during subacute poisoning with various toxicants. Bull Exp Biol Med 2008, 146:234-236.

43. Sawale SD, Ambhore PD, Pawar PP, Pathak U, Deb U, Satpute RM: Ameliorating effect of S-2( $\omega$-aminoalkylamino) alkylaryl sulfide (DRDE-07) on sulfur mustard analogue, 2-chloroethyl ethyl sulfide-induced oxidative stress and inflammation. Toxicol Mech Methods 2013, 23:702-710

44. Yego EC, Dillman JF 3rd: Cytokine regulation by MAPK activated kinase 2 in keratinocytes exposed to sulfur mustard. Toxicol In Vitro 2013, 27:2067-2075

45. Panahi Y, Davoudi SM, Beiraghdar F, Amiri M, Saadat A, Marzony ET, Naghizadeh MM, Sahebkar A: Serum levels of interleukins 2, 4, 6, and 10 in veterans with chronic sulfur mustard-induced pruritus: a cross-sectional study. Skinmed 2013, 11:205-209.

46. Wigenstam E, Rocksen D, Ekstrand-Hammarstrom B, Bucht A: Treatment with dexamethasone or liposome-encapsuled vitamin $\mathrm{E}$ provides beneficial effects after chemical-induced lung injury. Inhal Toxicol 2009, 21:958-964

47. Dillman JF 3rd, McGary KL, Schlager JJ: An inhibitor of p38 MAP kinase downregulates cytokine release induced by sulfur mustard exposure in human epidermal keratinocytes. Toxicol In Vitro 2004, 18:593-599

48. Attaran D, Lari SM, Towhidi M, Marallu HG, Ayatollahi H, Khajehdaluee M, Ghanei M, Basiri R: Interleukin-6 and airflow limitation in chemical warfare patients with chronic obstructive pulmonary disease. Int J Chron Obstruct Pulmon Dis 2010, 5:335-340.

49. Arroyo CM, Broomfield CA, Hackley BE Jr: The role of interleukin- 6 (IL-6) in human sulfur mustard (HD) toxicology. Int J Toxicol 2001, 20:281-296

50. Goldman M, Velu T: Interleukin-10 and its implications for immunopathology. Adv Nephrol Necker Hosp 1995, 24:79-90.

51. Elenkov IJ, Chrousos GP, Wilder RL: Neuroendocrine regulation of IL-12 and TNF-alpha/IL-10 balance. Clinical implications. Ann N Y Acad Sci 2000, 917:94-105.

52. Alipour R, Adib M, Masoumi Karimi M, Hashemi-Beni B, Sereshki N Comparing the Immunoregulatory Effects of Stem Cells from Human Exfoliated Deciduous Teeth and Bone Marrow-derived Mesenchymal Stem Cells. Iran J Allergy Asthma Immunol 2013, 12:331-344.

53. Fu WL, Zhou CY, Yu JK: A new source of mesenchymal stem cells for articular cartilage repair: MSCs derived from mobilized peripheral blood share similar biological characteristics in vitro and chondrogenesis in vivo as MSCs from bone marrow in a rabbit model. Am J Sports Med 2014, 42:592-601.

54. Ruff AL, Dillman JF: Signaling molecules in sulfur mustard-induced cutaneous injury. Eplasty 2007, 8:e2. 
55. Jowsey PA, Williams FM, Blain PG: DNA damage, signalling and repair after exposure of cells to the sulphur mustard analogue 2-chloroethyl ethyl sulphide. Toxicology 2009, 257:105-112.

56. Langenberg JP, van der Schans GP, Spruit HE, Kuijpers WC, Mars-Groenendijk RH, van Dijk-Knijnenburg HC, Trap HC, van Helden HP, Benschop HP:

Toxicokinetics of sulfur mustard and its DNA-adducts in the hairless guinea pig. Drug Chem Toxicol 1998, 21(Suppl 1):131-147.

\section{Submit your next manuscript to BioMed Central} and take full advantage of:

- Convenient online submission

- Thorough peer review

- No space constraints or color figure charges

- Immediate publication on acceptance

- Inclusion in PubMed, CAS, Scopus and Google Scholar

- Research which is freely available for redistribution 